\title{
エコチル調查の概要と遺伝子解析の位置づけ
}

\author{
新田裕史 \\ 国立研究開発法人国立環境研究所環境健康研究センター
}

\section{Outline of the Japan Environment and Children's Study and the Framework of Genome Analysis}

\author{
Hiroshi NITTA \\ National Institute for Environmental Studies, Environmental Health Sciences Division
}

\begin{abstract}
The goal of the Japan Environment and Children's Study (JECS) is to improve the health and welfare of children and to contribute to better risk management of chemical substances in the environment. The study will examine hypotheses related to reproduction, congenital anomalies, neuropsychiatric development, immunity, metabolism and endocrine system. The hypotheses will be tested for indicative outcomes in combination with exposure to chemicals, as well as confounders and modulators, such as chemical, physical, genetic, social and lifestyle-related factors. A total of 100,000 pregnant women associated with the selected study locations were recruited during the first three years starting January 2011. Their children will be followed up until the age of 13 years. The main study (nationwide survey) will include all participants recruited in all regional centres. Substudies will be conducted on randomly selected individuals from among all the participants. In the main and substudies, blood, urine, hair and breast milk samples will be collected from mothers. Blood, hair, and urine samples as well as umbilical cord blood at delivery will be collected from the children. Blood samples will also be collected from fathers. Each specimen will be analysed for specific chemical substances. In addition, genetic background will be evaluated. The collected blood samples for genetic assessments will be stored at the national centre. The detailed assessment procedures will be reviewed for approval by IRBs.
\end{abstract}

Key words: epidemiological study（疫学研究）, birth cohort（出生コホート), chemical substances（化学物質）

1. エコチル調査の概要

\section{1. 経緯}

エコチル調査といら愛称で呼ばれている「子どもの健 康と環境に関する全国調査」は, 環境要因が子どもの健 康に与える影響を明らかにすることを目的とする疫学調 査であり, 環境要因の中でも特に化学物質の曝露や生活 環境が胎児期から小児期にわたる子どもの健康にどのよ らな影響を与えているのかについて明らかにし，化学物 質等の適切なりスク管理体制の構築につなげるために, 環境省の調査研究事業として計画されたものである。エ コチル調査は化学物質の健康影響解明を主眼においてい

受付 2015 年 3 月 23 日, 受理 2015 年 4 月 15 日

Reprint requests to: Hiroshi NITTA

National Institute for Environmental Studies, Environmental Health Sciences Division, 16-2 Onogawa, Tsukuba, Ibaraki 305-8506, Japan E-mail: nitta@nies.go.jp
るものの，狭義の環境化学物質の影響解明のみを目的と するものではなく，大気污染をはじめとする幅広い環境 要因をその検討対象としている。さらに, 子ぞもの健康 には環境污染以外に多くの要因が関わることから，エコ チル調査では多様な要因を把握した上で，環境污染の影 響を評価できるように設計されている。

環境省がエコチル調査を企画する端緒となったのは, 1997 年に米国で開催された G8 環境大臣会合に扔ける 「子ぞもの健康と環境」に関する宣言である。環境省で は 2006 年に専門家による検討をはじめて扮り，その後 のさまざまな検討を経て，2010年 3 月には「子ぞもの 健康と環境に関する全国調査（エコチル調査）」基本計 画を公表して調査開始の準備を開始した。

\section{2. 調查方法}

エコチル調査では, 環境要因と妊娠・生殖, 先天奇形, 精神神経発達, 免疫・アレルギー, 代謝・内分泌等の各 
分野のアウトカムとの関連性関する仮説を設定し，そ れらの仮説を検討するために必要な調査を実施すること を基本的な枠組みとして研究計画が立案された。調査は 公募で選定された全国 15 地域の大学等の研究機関がユ ニットセンターと呼ぶ地域組織を構築して, リクルート 及び追跡調査等を担当する。また, 国立環境研究所に中 央事務局にあたるコアセンターが置かれるとともに, 国 立成育医療研究センターに臨床医学面から支援するメ ディカルサポートセンターが設置されている。リクルー 卜は 2011 年 1 月から 2014 年 3 月までの間実施され, 最 終的に 10 万組の母親と子ぞもの参加を目標とした。ま た, 追跡調查は子どもが 13 歳に達するまで継続し, そ の後の解析期間を加光ると 20 年に及ぶ長期間の調查で ある。

調查対象者は, 出産予定日が 2011 年 8 月 1 日からリ クルート期間終了までの妊婦であり, リクルート期間中 にユニットセンターが指定した調查地区に居住し,かつ, 将来的にも日本国内に居住することが予定され，ユニッ トセンターが指定する協力医療機関を受診もしくは母子 健康手帳交付申請を行った妊婦である。協力医療機関や 自治体の協力のもとに，こ和らの条件に合致する娃婦か らインフォームド・コンセントを受けて実施する。妊婦 （母親）からは自分自身の調查参加と共に子どもの調查 参加に関する代諾者としてインフォームド・コンセント を受ける。また, 子どもの父親も調査対象者として, 妊 婦（母親）とは別にインフォームド・コンセントを受け る。

エコチル調査では調査対象者全員に対して統一した方 法で実施する「全体調査」, 全対象者から抽出した一部 対象者（5,000 人規模）に対して詳細な医学的検査・環 境測定などを実施する「詳細調査」, 及び各地域での調 査を担当するユニットセンター等が調査対象者の一部ま たは全部を対象として独自の調査内容を加えて実施する 「追加調查」の3 種類の調查を実施する。

\section{(1) 全体調査の内容}

全体調査では, 妊婦を対象とした妊娠前期と中後期に それぞれ 1 回の質問票調査, 妊娠期, 出産時, 出産後 1 ヶ 月検診時に診察記録などの医療情報の収集を行う。出産 後については 6 个月おきに継続して質問票調査などに よって種々のアウトカムや関連要因に関する情報を収集 する。

質問票や診察記録票の内容はすべての地域で統一され たものである。妊娠期の質問票には，婚姻状況，家族， 妊娠歴, 既往歷, 薬剂使用歴, 抑うつ性障害, 不安障害, 健康関連 QOL，身体活動，喫煙，職業，食物摄取頻度， 飲酒なぞに関する質問が含まれる。さらに, 出生後の質 問票では疾患罹患状況, 子どもの成長記録, 精神神経発 達, 家族関係, 母の健康, 養育環境, 生活習慣, 社会生 活，居住環境などに関する質問が含まれる。

また, 妊婦や父親からの採血・採尿, 出産時には臍帯 血の採取, 毛髪（母親及び子ども）の採取, 生後 1 ヶ月
には母乳の採取を行ら。調查対象者から採取された血液・ 尿などの生体試料は, 生化学検査 ( $\mathrm{HbAlc}$, 特異的 $\operatorname{IgE}$ ( ス

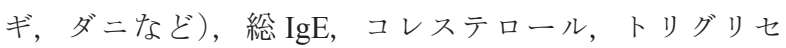
リド，総たんぱく質，アルブミン，リン脂質，葉酸なぞ） を実施するともに, いくつかの保存容器に分注した後に,

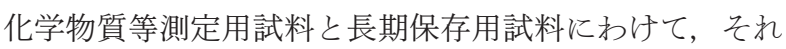
ぞれ異なる施設で保管される。生体試料中の化学物質等 の測定はリクルート期間終了後に, 順次実施さ扎る予定 である。長期保存用試料関する分析項目は現時点では 未定であり, 将来新た問題が生じた場合などを想定して 保存される。また, エコチル調査では将来の遺伝子解析 のために保管し，研究に使用することを説明して，調査 参加の同意を得て和り, 遺伝子解析用血液試料として保 存している。生体試料中の化学物質等の測定は POPs, ダイオキシン，金属類など多数の項目について実施され る予定である。

なお，これらの化学物質等は全ての参加者の試料につ いて全項目を分析するのではなく，一部の化学物質につ いてはコホート内症例対照研究などの疫学デザインに基 らいて，分析対象とする参加者の試料を選択することに なっている。

\section{(2) 詳細調査の概要}

詳細調査は, 全体調査対象者の中の適格条件に合ら候 補者から無作為飞選び, 同意を得た 5,000 人を対象とし て, 全体調查で行ら項目に加えて, アウトカム評価や曝 露評価の実施上の困難さから全体調査では実施ができな い, より詳細な内容について実施する。詳細調査の対象 者数は全体調査リクルート数に比例して, 各ユニット七 ンターに割り当てられている。調査内容は参加者の家庭

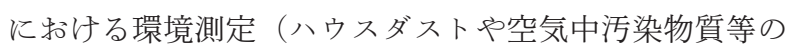
測定等), 精神神経発達検查及び医学的検査（採血を含 む。)となっている。調査時期については, 環境測定は 1.5 歳と 3 歳時点の 2 回, 精神神経発達検査及び医学的検查 は 2 歳, 4 歳となっている。6 歳以降の調查は, 今後さ らに検討を加光た上で決定する計画である。

\section{(3) 追加調査の概要}

追加調查は, 全体調査・詳細調査の調査項目に加えて, ユニットセンタ一等が独自の計画及び予算に基づいて, 調査対象者の一部または全部を対象として行ら調査であ る。本体の全体調査・詳細調査に影響を与えない範囲で, 事前に環境省の承認を受けて実施する。

\section{2. 調査の進渉}

2014 年 3 月末でリクルート期間は終了し, 参加者（娃 婦）の登録数は約 10 万 3 千名となった。声かけ数に対 する同意者の割合は約 79\%であった。父親の登録数は 約 5 万 2 千名, 出生した子ぞもは約 9 万 9 千名である。 出生後 6 个月毎に郵送法で実施している質問票調查は, 出後 6 ケ月, 1 歳, 1.5 歳, 2 歳, 2.5 歳, 3 歳, 及び 3.5 歳質問票調查が進行中である。これまでの質問票調查の 
回収率は $90 \%$ 前後で推移している。また，妊娠期から 生後 1 ヶ月までの各種生体試料の採取は終了し，化学分 析用試料及び遺伝子解析用試料は保管施設に打いて $-80^{\circ} \mathrm{C}$ で保管されるとともに，化学分析用試料の一部 は金属等の化学分析が行われている。また，長期保管用 試料は液化窒素タンクに拈いて保管されている。

さらに, 詳細調査が開始されて，1.5 歳時点の参加者 の家庭に打ける環境測定が進められている。2015 年4月 からは精神神経発達検査及び医学的検査が開始される。

\section{3. エコチル調査における遺伝子解析の位置づけ}

エコチル調査では遺伝子解析について，「血液等を将 来の遺伝子解析のために保管し, 研究に使わせていただ きます。遺伝子解析に関して具体的な研究計画ができま したら, その時点で倫理審査を受け，必要な手順を踏ん で研究を進めます。といら説明を行って同意を受領し ている。

エコチル調査では, 母親血液, 臍帯血, 及び父親血液 の全血試料と子どものろ紙血試料が遺伝子解析用に保管 されている。

現在，遺伝子解析に関する具体的な計画を検討中であ り，計画策定後に倫理的な手続きを進めた上で，解析を 進めることになる。基本方針としては，第一次計画と第 二次計画の二つのフェーズに分けて検討を進めることと している。第一次計画では, エコチル調査の中心仮説で ある環境化学物質と種々のアウトカムとの関連性につい て, 既存の知見の中でゲノムの観点から解析を行ってい るものを整理して, 候補となりらる SNPs 等の解析対象 をリストアップする予定である。第二次計画は, 全ゲ, ム解析, GWAS 等を含む最新のゲノム解析を念頭に置 いて, 他省庁に拈けるゲノム疫学研究の動向も踏まえて,
予算計画，説明・同意プロセスの検討，解析計画の立案 を行らことを想定している。第一次並びに第二次計画と もに，倫理指針を踏まえて，倫理上の問題を十分に検討 した上で計画案を策定することになる。

\section{4. おわりに}

エコチル調査の基本計画は 5 年前に立てられたもので あり，その間のゲノム解析の進歩は著しい。遺伝子解析 に関するエコチル調査のインフォームド・コンセントの 内容については，遺伝子解析を前提とした生体試料の保 管と使用となって扣り，具体的な解析内容を明示したう えでの同意でない。エコチル調査は親子を対象とした調 査であり，倫理的課題についてはより慎重な検討が必要 であると考えている。

エコチル調査に拈ける遺伝子解析の位置づけについ て，その曖昧さを指摘されることもあるが，最新の解析 方法を採用できる可能性を保持しつつ, 今後, 計画を具 体化し，それとともに倫理的な手続きを適切に実施する ことによって，エコチル調査の目標を達成できると考光 ている。

利益相反なし

\section{参考資料}

Kawamoto T, Nitta H, Murata K, Toda E, Tsukamoto N, Hasegawa $\mathrm{M}$, et al. Rationale and study design of the Japan environment and children's study (JECS). BMC Public Health 2014;14:25.

エコチル調査の研究計画書等の関係資料は，環境省エコチ ル調査 HP : http://www.env.go.jp/chemi/ceh/に打いて公開 されている（最終アクセス日 2015 年 3 月 24 日） 